\title{
КОРПУС ЛИНГВИСТИКАСИДА ПОЛИСЕМИЯ
}

\author{
Абдурахманова Мукаддас Турсуналиевна \\ Мирзо Улуғбек номидаги Ўзбекистон Миллий университети \\ доценти, филология фанлари номзоди \\ Рахманова Азизахон Абдугафуровна \\ azizahonraa@gmail.com
}

Мирзо Улуғбек номидаги Ўзбекистон Миллий университети

таянч докторанти

Аннотация: Мақолада компьютер усуллари, хусусан коллакаций, яъни семантик қуршовдан фойдаланиш усули кўп маъноли сўзлар семантикасини ўзлаштиришда, таржима жараёнида муқобил бирликларни танлашда ахамиятли эканлиги ёритиб берилган. Полисемик сўзларнинг маънолари синтактик қуршов таркибида тахлил қилинган.

Калит сўзлари: корпус, омонимия, полисемия, разметка, семантик қуршов

Жахон корпус лингвистикасида туркум омонимиясини морфологик разметкада баратарф этиш учун қуршовдан (олдин ёки кейин келган сўздан:правые и левые коллокаты) фойдаланилади. Бирикма сўзнинг қайси туркумга мансублигини аниқ кўрсатиб туради [1].

Коллокаций (правые и левые коллокаты - биз бу усулни “синтактик қуршов” деб номладик) усулини полисемантик сўзларни тахлил қилишда хам қўллаш мумкин. Фақат бу ўринда туркий тиллар, хусусан, ўзбек тилининг ўзига хос табиати намоён бўлади: бунда бирикмалардаги тобе хокимлик муносабатига асосланилади. Ўзбек тилининг ўзига хослиги шунда кўринадики, бунда сўзнинг ўнг ёки чап томонида турган қисм, деб эмас, олдин ёки кейин келган сўз деб ажратиш тўғрироқ бўлади. Ўзбек тилида, баъзан, ёнма-ён келган сўз боғланмаслиги хам мумкин: Унинг отаси бош чўпон, уузи эса чўпон ёрдамчиси бўлиб ишлай бошлади жумласида бош чуцпон сўзи билан бирикма хуосил қуилади, лекин ундан олдин келган отаси суизиакли билан синтактик муносабатга киришмайди, хуоким тобелик асосида бирикмайди. Бунда бирикмалар омоним сўзнинг қайси варианти қўлланганини кўрсатиб турганидек, полисемантик сўзнинг қайси маъноси реаллашаётганига аниқлик киритади. 
Семантик куршов усулини ўзбек тилида кўлланиш частотаси хамда кўчим хосил қилиш имконият юқори бўлган бош лексемаси мисолида кўриб чиқиш мумкин. Ўзбек тилида бош кўп маъноли сўз бўлиб, мазкур сўз асосидаги полисемияни корпус ёрдамида англаш мумкин. Информацион қидирув тизими бош иштирок этган матнларни ажратиб беради. Бош тананинг бўйиндан юқориги, олдинги (одамда, хайвонларда) қисми; калла. Корпус мазкур сўзнинг изохли луғатдан олинган матн таркибида 20 ўринда кўлланганини, 60та ибора таркибида келганини кўрсатади. Мазкур сўзнинг маъноларини синтактик қуршов таркибида кўриб чиқамиз:

\begin{tabular}{|c|c|c|c|}
\hline № & $\begin{array}{l}\text { Бош бирлиги иштирокидаги } \\
\text { контекст }\end{array}$ & $\begin{array}{l}\text { Бош сўзидан олдинги } \\
\text { ёки кейинги қисм }\end{array}$ & $\begin{array}{l}\text { Бош лексемаси } \\
\text { асосида } \\
\text { реаллашадиган маъно }\end{array}$ \\
\hline 1. & $\begin{array}{l}\text { Ўзбек ойим боши билан келинига ризолик } \\
\text { билдириб, «баракалла!» деб куйди. }\end{array}$ & $\begin{array}{l}0 \rightarrow \text { боши билан; } \\
\text { бош+г.ш.+Г.в. } \rightarrow \\
\text { билдириб }\end{array}$ & $\begin{array}{l}\text { тананинг бўйиндан юқориги, } \\
\text { олдинги (одамда, хайвонларда) } \\
\text { қисми; калла. }\end{array}$ \\
\hline 2. & $\begin{array}{l}\text { Товнинг куурки тош билан, одамнинг кўрки } \\
\text { бош билан. }\end{array}$ & $\begin{array}{l}\text { куурки } \rightarrow \text { бош билан; } \\
\text { боши +Г.в. } \rightarrow 0\end{array}$ & “ақл-хуш, мия” \\
\hline 3. & Яхии хотин эрни элга бош қ̧илур... & $\begin{array}{l}\text { элга } \rightarrow \text { бош }+ \text { қилур; } \\
\text { боши }+ \text { қиллмоқ̧ } \rightarrow 0\end{array}$ & “бошлиқ, рахбар" \\
\hline 4. & $\begin{array}{l}\text { Директорнинг бу гапи бош инженерга } \\
\text { қ̧аймоққай ёқцб кетди. }\end{array}$ & $\begin{array}{l}0 \rightarrow \text { бош; } \\
\text { бои } \rightarrow \text { инженер }\end{array}$ & $\begin{array}{l}\text { “лавозим, мансаб жихатдан } \\
\text { катта, юқори турувчи” }\end{array}$ \\
\hline 5. & Мана Хоразмнинг жанубий бош дарвозаси. & $\begin{array}{l}0 \rightarrow \text { бои; } \\
\text { бои } \rightarrow \text { арвоза }\end{array}$ & “улкан, катта, асосий” \\
\hline 6. & $\begin{array}{l}\text { Кейинчалик мактаб сахунасида ўйналадиган } \\
\text { спектаклларда хуамиша бош ролларни ижро } \\
\text { этадиган бўлди. }\end{array}$ & $\begin{array}{l}0 \rightarrow \text { бош; } \\
\text { бош } \rightarrow \text { роллар }\end{array}$ & “энг мухим, асосий, етакчи” \\
\hline 7. & $\begin{array}{l}\text { Ёщи улгайганда уйланганидан, бош боласи } \\
\text { мен эдим. }\end{array}$ & $\begin{array}{l}0 \rightarrow \text { бош; } \\
\text { бош } \rightarrow \text { боласи }\end{array}$ & “энг олдинги, биринчи”, \\
\hline 8. & Бир бошга юзта хўжайин бор. & $\begin{array}{l}\text { бир } \rightarrow \text { бошга; } \\
\text { бош }+ \text { г.ш. } \rightarrow \text { бордир }\end{array}$ & “одам, киши”, \\
\hline 9. & $\begin{array}{l}\text { Хар бош сигирдан икки ярим минг литрдан } \\
\text { сут совиб олинди. }\end{array}$ & $\begin{array}{l}\text { хуар } \rightarrow \text { бош } \\
\text { бош } \rightarrow \text { сигир }\end{array}$ & хисоб сўзи“адад”, “дона”, \\
\hline 10. & $\begin{array}{l}\text { Куёш тик куттарилиб.. } \\
\text { майсаларнинг боши эгилди. }\end{array}$ & $\begin{array}{l}\text { майсалар+г.ш. } \rightarrow \text { боши; } \\
\text { бош }+ \text { г.ш. } \rightarrow \text { эгилди. }\end{array}$ & $\begin{array}{l}\text { “тик нарсаларнинг тепа қисми, } \\
\text { учи, чўққиси”, }\end{array}$ \\
\hline 11. & $\begin{array}{l}\text { Юринг, холажон, қизни ўзим топаман, } \\
\text { туйнинг бошида ўзим бўламан, ёр-ёрни хуам } \\
\text { ўзим айтаман.. }\end{array}$ & 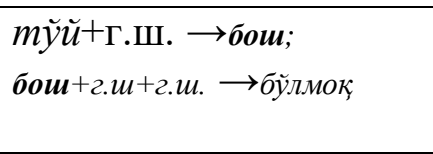 & $\begin{array}{l}\text { “бирор маросим, тадбир, воқеа- } \\
\text { ходисанинг рўй бериш, амалга } \\
\text { ошиш жараёнидаги дастлабки } \\
\text { босқич” }\end{array}$ \\
\hline 12. & $\begin{array}{l}\text { Саидмурод ака хашакчилар бошига } \\
\text { борганда, улар тушликка чиқишган экан. }\end{array}$ & $\begin{array}{l}\text { хамакчилар + } \rightarrow \text { бошига; } \\
\text { бош }+2 . ш+2 . ш . \longrightarrow \text { борганда }\end{array}$ & “ён, олд, томон”, \\
\hline 13. & $\begin{array}{l}. . \check{р н и д а н ~ д и к ~ э т и б ~ т у р и б, ~ к а р а в о т ~ б о ш и г а ~} \\
\text { ташлаб куйилган шимнинг камарини сувуриб } \\
\text { олди. }\end{array}$ & $\begin{array}{l}\text { каравот } \longrightarrow \text { бошига; } \\
\text { бош }+2 . u .+2 . ш . \longrightarrow \text { ташлаб }\end{array}$ & $\begin{array}{l}\text { “ўрин, каравот ва ш. к. нинг } \\
\text { бош куйи-ладиган юқори } \\
\text { томони”, “шундай ўринда ётган } \\
\text { кишининг белдан юқори } \\
\text { томонидаги жой” }\end{array}$ \\
\hline
\end{tabular}




\begin{tabular}{|c|c|c|c|}
\hline 14. & $\begin{array}{l}\text { Отам машъалани тутиб, охур бошига } \\
\text { бордилар. }\end{array}$ & $\begin{array}{l}\text { охур }+\boldsymbol{\varnothing} \longrightarrow \text { боши; } \\
\text { бош }+2 . u .+2 . u . \rightarrow \text { бордилар }\end{array}$ & $\begin{array}{l}\text { баъзи отлар билан бирикиб, шу } \\
\text { от орқали ифодаланган } \\
\text { нарсанинг уузини ёки у } \\
\text { ўрнашган жойни, ён-атрофини } \\
\text { билдиради; }\end{array}$ \\
\hline 15. & $\begin{array}{l}\text { Аваз дала бошида, омонат бир чайла } \\
\text { соясида соч олиб турарди }\end{array}$ & $\begin{array}{l}\text { дала+ } \\
\longrightarrow \text { бошида; } \\
\text { бош+2.u.+2.u. } \rightarrow \text { соч ОЛиб }\end{array}$ & $\begin{array}{l}\text { Чўзиқ, давомли, бўйли } \\
\text { нарсалар, жой, майдонларнинг } \\
\text { бошланиш жойи ёки охири, } \\
\text { этаги; шундай нарсаларнинг } \\
\text { икки учидан, чеккасидан, } \\
\text { томонидан бири. }\end{array}$ \\
\hline 16. & $\begin{array}{l}\text { Тўти бу хатнинг бошини эщитибоку, уззини } \\
\text { ерга куттариб урган эди. }\end{array}$ & $\begin{array}{l}\text { хат+2.u. } \rightarrow \text { бошини; } \\
\text { боши }+2 . u .+2 . u . \rightarrow \text { эиитиб. }\end{array}$ & $\begin{array}{l}\text { Воқеа, ходисанинг, бирор } \\
\text { муддат ёки фаслнинг, асар, } \\
\text { матн ва ш. к. нинг бошла-ниш } \\
\text { жойи, } \\
\text { муқаддимаси. }\end{array}$ \\
\hline 17. & $\begin{array}{l}\text { Уйин-кулгимизнинг боши Бахрихоннинг туйи } \\
\text { бўлади, - деди. }\end{array}$ & $\begin{array}{l}\text { кулги+г.u.+2.u. } \rightarrow \text { боши; } \\
\text { бош+2.u. } \rightarrow \text { туйи +бўлади }\end{array}$ & $\begin{array}{l}\text { воқеа, ходисанинг, } \\
\text { муддат ёки фаслнинг, асар, } \\
\text { матн ва ш. к. нинг бошланиш } \\
\text { жойи, } \\
\text { муқаддимаси” }\end{array}$ \\
\hline 18. & $\begin{array}{l}\text { Пеш-тахта олдига бориб, саватдаги } \\
\text { узумдан бир бош танлади-да, тарози } \\
\text { палласига куйди. }\end{array}$ & $\begin{array}{l}\text { бир } \longrightarrow \text { бош; } \\
\text { бош } \longrightarrow \text { танлади }\end{array}$ & $\begin{array}{l}\text { Баъзи ўсимликларнинг калла } \\
\text { ёки чочоқ шаклидаги хосили, } \\
\text { меваси. }\end{array}$ \\
\hline 19. & Беш бош құилиб олмок.. & 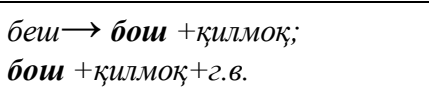 & Карра хисоб \\
\hline 20. & Йўл бошига, йўл бошидан [2]. & йўл $\longrightarrow$ боши & Чегара \\
\hline
\end{tabular}

Бош сўзидан олдин келган сўзларнинг унга тобеланмаслиги кузатилди $(1,4,5.6)$; Икки ўринда билан кўмакчи воситаси билан бирга келган $(1,2)$. Икки ўринда қилмоқ ёрдамчи феъли билан бирикиб, кўшма феъл сифатида шаклланган $(3,19)$. Бу ўринда билан кўмакчисини, қилмоқ ёрдамчи феълини бош сўзидан кейин келган бирлик сифатида хисоблаш тўғри эмас (дастур шу тартибда ёндашади); билан воситаси бош сўзининг грамматик, құлмоқ̧ эса семантик таркибига тегишли қисмлар хисобланади. Бош сўзига тобеланган қисм аксарият холда битишув усулида бирикади $(8,9,18,19)$. Бош сўзи саккиз ўринда ўзидан олдинги қисмни мослашув усулида тобелантириб келган $(10,11,12,13,14,15,16,17)$. Шундан тўрт ўринда мослашув грамматик шакл орқали ифодаланган $(10,11,16,17)$. Қолган тўрт ўринда грамматик маъно белгисиз ифодаланган $(12,13,14,15)$. Беш ўринда бош сўзи ўзидан кейинги қисмга битишув усулида бириккан $(4,5,6,7,9)[2]$.

С.Адилова корпус асосидаги таълим хақида сўз юритар экан, яратилиши режалаштирилаётган ўзбек тилининг корпуси талабага катта ёрдам беришини таъкидлайди. Талаба қисқа муддат ичида сўзнинг полисемантиклигини тушунади, турли маъноларни ифодалаши, алохида кўшимчалар билан кўлланиши, бошқа сўзлар билан бирикиши, жуфт ва такрорий шаклда келиши, оғзаки нуткда ишлатилиши, эмоционал-экспрессив хусусиятлари хақида билимга эга бўлади [3].

Синтактик қуршов методи кўп маъноли сўзнинг туркум хусусиятларини намоён этмайди. Бу холат кўп маъноли сўзнинг бир сўз эканлиги ва барча ўринларда ундан олдин ёки кейин келган қисм бир хил грамматик маънонинг 
реаллашувига хизмат қилиши маълум бўлди. Синтактик куршов кўп маъноли лексемадан олдинги ва кейинги қисмларнинг иштирокини, бу қисмларнинг марказий лексемага боғланиш усулларини, грамматик маъно ифодаловчи воситалар иштирокини кўрсатишга хизмат қилади.

Ўзбек тилидаги матнлар базасига асосланган корпус тузилса, бош сўзи куйидаги "I will" бирикмасини тизиб, контекстуал маъноларини талқин килгани каби анализ килади:

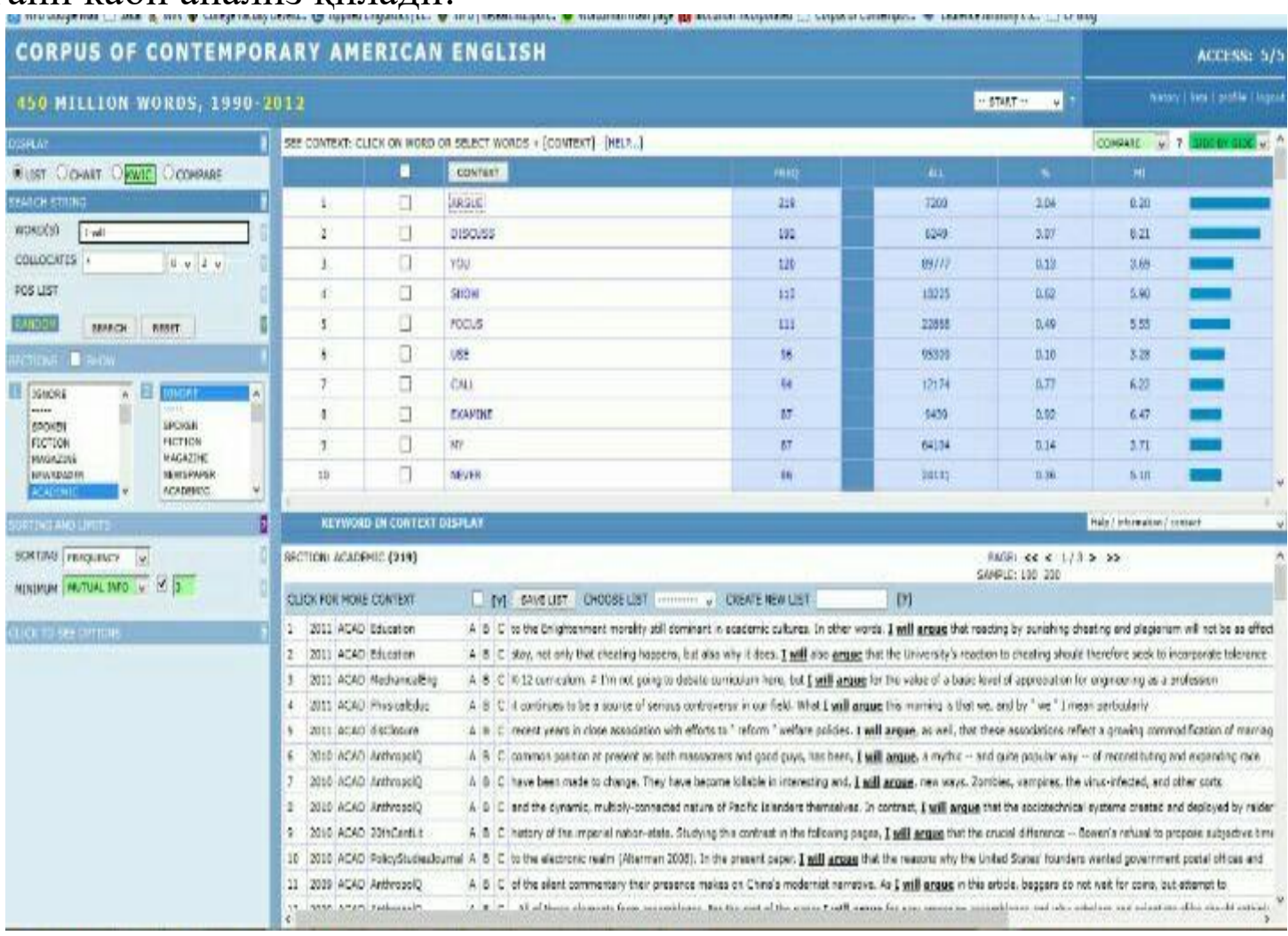

Сўзларнинг кўлланишини шунчаки хисоб-китоб қилиш хеч нарса бермайди. Муайян сўз кўлланиши юзасидан олиб борилган статистика уни шу матндаги бошқа сўзларнинг қўлланиш миқдори билан ёки диахрон усулда, ёки жанрлар бўйича қиёсланганда амалий ахамиятга эга бўлади. Бундай маълумотни конкорданслар ёрдамида олиш мумкин бўлади [1].

\section{Фойдаланилган адабиётлар:}

1. Богданова С.Ю. Исследование слова и предложения компьютерными методами // Слово в предложении: кол. монография / Под ред. Л.М. Ковалевой (отв. ред), С.Ю. Богдановой, Т.И. Семеновой. Иркутск: ИГЛУ, 2010.

2. Ўзбек тилининг изохли луғати. I. - Т.: Ўзбекистон миллий энциклопедияси, 2006. - Б. 332-340.

3. Адилова С. Corpus linguistics and its role in teaching uzbek as a foreign language. O`zbek tili taraqqiyoti va xalqaro hamkorlik masalalari. Toshkent, 2019. -P.393. 